\title{
DUODENAL BYPASS DOES NOT DECREASE GLUCOSE LEVELS OF LEAN INDIVIDUALS WITH GASTRIC CANCER SUBMITTED TO PARTIAL OR TOTAL GASTRECTOMY
}

\author{
Fernando A. HERBELLA, Ana C. TINELI, Jorge L. WILSON Jr. and Jose C. Del GRANDE
}

\begin{abstract}
Change in glucose metabolism after bariatric operations may be credited to duodenal bypass. This study aims to evaluate the effect of duodenal bypass on glucose levels in lean individuals submitted to gastrectomy for gastric cancer. We reviewed 56 non-diabetic and 6 diabetic patients submitted to gastrectomy and Roux-en-Y for gastric cancer (partial gastrectomy in $66 \% /$ total gastrectomy in 34\%). Glucose levels were not significantly altered after operation $(P=0.5)$. Diabetes control was improved in one patient with oral medication. In conclusion, duodenal bypass do not decrease glucose levels in lean individuals treated for gastric cancer. HEADINGS - Anastomosis, Roux-en-Y. Diabetes mellitus. Gastrectomy. Stomach neoplasms.
\end{abstract}

\section{INTRODUCTION}

Bariatric surgery leads to marked amelioration of some obesity-related comorbid conditions, including diabetes mellitus ${ }^{(1)}$. Surprisingly, it has been suggested that glucose metabolism is improved in these patients irrespective of weight $\operatorname{loss}^{(1)}$.

The exact mechanisms responsible for diabetes control after bariatric surgery are still not clearly identified; however, weight loss, caloric restriction and modifications in the enteroinsular axis are putative factors ${ }^{(1,2)}$. In view of the fact that duodenal bypass may be contributory to these enteroinsular hormones variations ${ }^{(2)}$ similar changes are expected in patients submitted to gastrectomy and Roux-en-Y reconstruction.

This study aims to evaluate the effect of duodenal bypass on glucose levels in lean individuals submitted to gastrectomy for gastric cancer.

\section{METHODS}

\section{Patients}

We reviewed 56 patients ( 36 males, mean age $61 \pm 11$ years, range 41-80 years) submitted to gastrectomy and Roux-en-Y reconstruction for gastric cancer between January, 2000 to July, 2006. Patients were excluded if obese $\left(\mathrm{BMI}>30 \mathrm{~kg} / \mathrm{m}^{2}\right)$, diabetic, submitted to palliative surgery, or with a follow-up lower than 1 month.

Six patients with the diagnosis of diabetes mellitus type 2 were analyzed separately (two treated with insulin, four with oral medication).

Partial gastrectomy was the operative approach in $37(66 \%)$ patients and total gastrectomy in $19(34 \%)$.

Glucose levels were measured the day before operation in all patients but did not follow specific clinical protocols after the operation. All measurements were taken in a fasting state. An average of four measurements was done in different periods per patient (range 1-11). Mean follow-up time was $16 \pm 15$ months (range 1-77 months).

\section{Statistics}

Kruskall-Wallis with Dunn's multiple comparison test and simple linear correlation (Pearson r) were used as indicated. Statistical significance was defined as $P<0.05$.

\section{RESULTS}

Glucose levels were not significantly altered after operation $(P=0.5)$. There were no correlations between glucose level and time of follow-up for the whole population $(r=0.0002)$, partial gastrectomy $(r=0.0001)$ or total gastrectomy $(r=0.0042)($ Figure 1$)$.

Department of Surgery, Division of Esophagus and Stomach, "Universidade Federal de São Paulo", São Paulo, SP, Brazil.

Presented as poster at the Digestive Disease Week, May 17-22, 2008, San Diego, California

Correspondence: Dr. Fernando A. M. Herbella - Hospital Sao Paulo, Surgical Gastroenterology, Division of Esophagus and Stomach - Rua Diogo de Faria, 1087 - cj 301

- 04037-003 - São Paulo, SP, Brazil. E-mail: herbella.dcir@unifesp.epm.br 


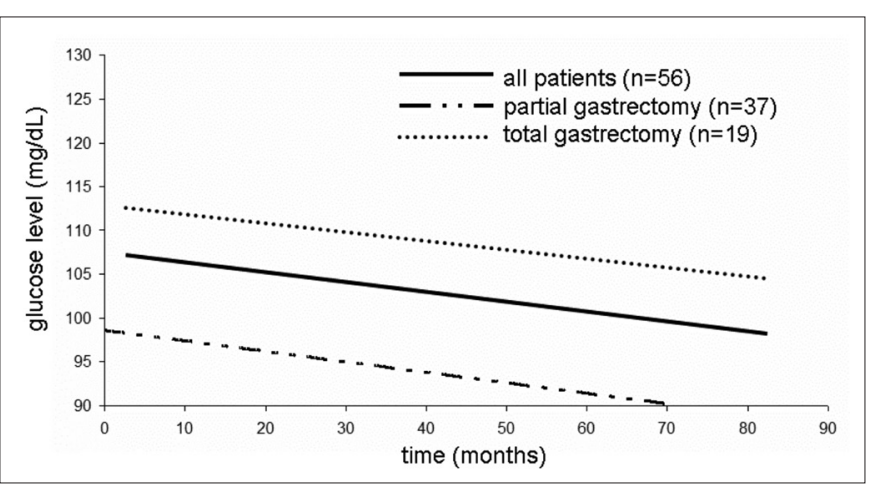

FIGURE 1. Glucose levels trend after operation

In the subgroup with previous diabetes, diabetes control was improved in one patient with oral medication (decrease in medication daily dosage).

\section{DISCUSSION}

Our results show that glucose levels were not significantly altered after duodenal bypass in lean individuals.

\section{Bariatric surgery and diabetes}

It is unnecessary to mention the incidence and social and financial impact of diabetes mellitus. Several studies demonstrated that diabetes can be cured after bariatric operations irrespective of weight $\operatorname{loss}{ }^{(1,2)}$. Impressive results, such as a significant reduction or abolition in use of oral antidiabetic agents or insulin in over $80 \%$ of the patients, are frequently reported ${ }^{(1)}$. Although caloric restriction may play a role in diabetes improvement, modification in the enteroinsular axis is probably responsible for this phenomenon. Different gut hormones ("incretins") have been implicated in the glucose metabolism ${ }^{(1)}$ and, possibly, many others remain to be discovered and studied. Support to link diabetes cure with change in gut hormones come from the fact that diabetes amelioration is suboptimal in restrictive only bariatric techniques such as gastric banding ${ }^{(1)}$ and that glucose level reduction occurs within days of the operation ${ }^{(1,2)}$.

\section{The role of duodenal bypass}

Some authors support that bypass of the duodenum and proximal jejunum is the key to the change in the beta-cell function. Some authors theorize that overstimulation of the proximal gut leads to hyperglycemia due to excessive production of incretins with a consequent hyperinsulinemia and insulin-resistance or impairment of incretins secretion.

Experimental studies in animals demonstrated that duodenal-jejunal bypass in non-obese diabetic rats improves glycemic control ${ }^{(3)}$. PACHECO et al. ${ }^{(3)}$ however, observed a significant decrease in leptin levels, but without changes in enteroinsular axis (GLP-1, GIP, glucagons, and insulin levels).

Clinical studies of duodenal-jejunal bypass are restricted to case reports. In view of the fact that duodenal bypass may be contributory to the enteroinsular axis changes, patients submitted to gastrectomy and Roux-en-Y reconstruction would constitute an experimental model of the procedure. However, our results do not support the theory that exclusion of the proximal intestine controls diabetes per se. In accordance to our findings, PATRITI et al. ${ }^{(4)}$ concluded that observing hormonal changes after bariatric operations there is little if any support for any effect of the upper digestive tract.

\section{The role of the gastric fundus}

Ghrelin is a hormone produced in the gastric fundus and it inhibits insulin release. Our study contemplated patients that underwent partial and total gastrectomy in an attempt to study the effects of ghrelin on glucose levels; however, in both groups of patients glycemia remained unchanged.

\section{The role of the hindgut}

It is suggested that early delivery of nutrient-rich chyme to the ileum is linked to diabetes control ${ }^{(5)}$. The phenomenon occurs when ingested food enters the ileum and discrete enteroendocrine cells in the mucosa release hormones that contribute to the ileal brake; noteworthy among these are glucagon-like peptide-1 (GLP-1) and peptide YY (PYY). Similar to duodenal bypass, ileal transposition improves glucose metabolism in experimental studies and clinical series.

Bariatric procedures are usually followed by exclusion of part of the proximal intestine and early delivery of partially digested food to the distal intestine, due to the creation of a long Roux limb. This mechanism is not contemplated in our study, since in our model of gastrectomy for cancer, a $40-\mathrm{cm}$ Roux limb is created in contrast to over $110 \mathrm{~cm}$ in bariatric procedures.

\section{Study limitations}

Our study has some limitations. A formal study of glucose tolerance and dosage of gut hormones and insulin was not done since it is a retrospective case series with a small number of diabetic patients. It is also unclear if the fact that patients had a malignant neoplasia may change results of the study.

\section{CONCLUSIONS}

Our results do not show effect of duodenal bypass on glucose levels. Also, resection of the proximal stomach and consequently abolition of ghrelin secretion do not alter glycemia. We may speculate that the hindgut may play the major role in diabetes cure after bariatric operations. As an indirect consequence of the duodenal exclusion surgery a portion of foregut is eliminated which is likely to also enhance the stimulation of hindgut or ileum what may explain good results obtained with duodenal bypass series.

We concluded that duodenal bypass do not decrease glucose levels in lean individuals treated for gastric cancer.

\section{ACKNOWLEDGEMENT}

We are indebted to Dr. Jorge Yamane for his invaluable assistance with laboratory data. 
Herbella FA, Tineli AC, Wilson Jr JL, Del Grande JC. O desvio do duodeno não diminui os níveis glicêmicos em indivíduos magros com câncer gástrico submetidos a gastrectomia parcial ou total. Arq Gastroenterol. 2009;46(3):230-2.

RESUMO - Alterações no metabolismo da glucose após cirúrgias bariátricas podem ser creditadas ao desvio do duodeno. Este estudo avaliou o efeito do desvio do duodeno nos níveis glicêmicos de pacientes magros submetidos a gastrectomia por câncer. Foram revistos 56 pacientes não-diabéticos e 6 pacientes diabéticos submetidos a gastrectomia com reconstrução em Y-de-Roux por câncer (gastrectomia parcial em 66\% e total em 34\%). Os níveis glicêmicos não se alteraram significantemente depois da operação $(P=0,5)$. Houve melhora do diabetes em um paciente com medicação oral. Em conclusão, o desvio duodenal não diminui os níveis glicêmicos de indivíduos magros tratados por câncer gástrico.

DESCRITORES - Anastomose em Y de Roux. Diabetes mellitus. Gastrectomia. Neoplasias gástricas.

\section{REFERENCES}

1. Greenway SE, Greenway FL 3rd, Klein S. Effects of obesity surgery on noninsulin-dependent diabetes mellitus. Arch Surg. 2002;137:1109-17.

2. Hickey MS, Pories WJ, MacDonald KG Jr, Cory KA, Dohm GL, Swanson MS, Israel RG, Barakat HA, Considine RV, Caro JF, Houmard JA. A new paradigm for type 2 diabetes mellitus: could it be a disease of the foregut? Ann Surg. 1998;227:637-43.
3. Pacheco D, de Luis DA, Romero A, González Sagrado M, Conde R, Izaola O, Aller $\mathrm{R}$, Delgado A. The effects of duodenal-jejunal exclusion on hormonal regulation of glucose metabolism in Goto-Kakizaki rats. Am J Surg. 2007;194:221-4.

4. Patriti A, Facchiano E, Sanna A, Gullà N, Donini A. The enteroinsular axis and the recovery from type 2 diabetes after bariatric surgery. Obes Surg. 2004;14:840-8.

5. Strader AD. Ileal transposition provides insight into the effectiveness of gastric bypass surgery. Physiol Behav. 2006;88:277-82. 